\title{
Screening of Antimicrobial Activity and Cytotoxic Potentiality of Ethanolic Leaf Extract of Ludwigia adscendens (L.) H.Hara
}

\author{
Shofi Uddin ANM11, Gazi MM11, Faysal AlM², Salauddin AlA2* Monirul \\ Islam $^{1}$ and Jannat Ara ${ }^{3}$ \\ 1Pharmacy Discipline, Life Science School, Khulna University, Bangladesh \\ ${ }^{2}$ Biotechnology and Genetic Engineering Discipline, Life Science School, Khulna \\ University, Bangladesh \\ ${ }^{3}$ Department of Pharmacy, Bangladesh University, Dhaka-1207, Bangladesh
}

\section{Research Article \\ Volume 3 Issue 4}

Received Date: September 27, 2018

Published Date: October 31, 2018

DOI: $10.23880 /$ apct- 16000139

*Corresponding author: Salauddin Al Azad, Biotechnology and Genetic Engineering Discipline, Life Science School, Khulna University, Khulna-9208, Bangladesh, Tel: +8801943187581; Email: abdullahsyum1992@gmail.com

\section{Abstract}

Background: Ludwigia adscendens (L.) H.Hara also known as water primrose which considers as weed in paddy field. Ludwigia species is used as traditional medicine widely and have possibilities to become as a therapeutic agent

Objective: To evaluate the cytotoxic and antimicrobial potential of using Ludwigia adscendens (L.) H.Hara plant extracts on experimental models in brine shrimp (in vivo) and disk diffusion methods (in vitro) respectively.

Materials and Methods: Acute antimicrobial experiments were performed by disk diffusion method through Determination of zone of inhibition in vitro condition and cytotoxic experiments were performed by brine shrimp lethality bioassay in this present study.

Results: Ludwigia adscendens (L.) H. Hara showed Significant in cytotoxic activity and moderate significant in antimicrobial against all pathogenic strains and activity increase proportionally with dose rate.

Conclusion: These studies conclude that Ludwigia adscendens (L.) H.Hara possesses good cytotoxic activity indicated by $\mathrm{LC}_{50}(96.6204 \mu \mathrm{g} / \mathrm{ml})$ determined by Ldp line probit analysis software and mild antimicrobial activity against some Gram positive and Gram negative bacterial species.

Keywords: Selective Cytotoxicity; Ethanolic Extract; Antimicrobial Activity; Ludwigiaspecies

\section{Introduction}

Ludwigia species is used as a traditional medicine widely which has been found through Asia, Australia and
Africa [1]. Species of these plants is playing active role to prevent heal dermatitis, boil, ulcer, impetigo and pimple [2]. Sometimes these can use as a health drink to prevent gastrointestinal complaints [3]. It is commonly known 


\section{Advances in Pharmacology and Clinical Trials}

that many pathogens are showing resistant against allopathic medicines [4]. Therefore it is necessary to introduce extensive research and technological development to produce safe phytopharmaceuticals from traditional plants may be bring the solution to reducing the wide range of diseases [5]. Plant species that has been used traditionally for therapeutic purposes should be screened for their bioactivities, where majority of these shows promising antimicrobial activity [6, 7]. Medicinal plant trade has a major impact throughout the world in maintaining public health [8]. Near about $80 \%$ people still used traditional medicine in the less developed countries [3]. Some of tradition plants in Asia show cytotoxic effect where majority of them used to treatment of various diseases such as cancer, inflammation or infectious diseases $[9,10]$. The majority of plant-associate natural products are phenolic compounds [11]. Anticancer activity also has been found to be associated with a variety of groups, such as polyphenols, flavonoids and catechins [12]. Ludwigia adscendens (L.) H.Hara has an adequate amount polyphenols, flavonoids in its body constituents. Therefore, in this present study we wanted to determine cytotoxic effect and antimicrobial activity of relatively new species called Ludwigia adscendens (L.) H.Hara in in vivo and in vitro condition respectively to serve it as a therapeutic medicine.

\section{Materials and Methods}

\section{Plant Material and Preparation of Extract}

The whole plant of L. adscendens (L.) H. Hara was collected from Jhenidha area, Bangladesh on January, 2012 and was identified by experts at Bangladesh National Herbarium, Mirpur, Dhaka. The collected plant parts were separated from undesirable materials, washed with water, sun-dried for one week and finally grinded into coarse powder with the help of a suitable grinder (Capacitor start motor, Wuhu motor factory, China). The powder was stored in an airtight container and kept in a cool, dark and dry place until analysis commenced. About $450 \mathrm{gm}$ of powered material was taken in a clean, flatbottomed glass container and soaked in $1600 \mathrm{ml}$ ethanol. The container with its contents was sealed and kept for a period of 8 days accompanying occasional shaking and stirring. The whole mixture then underwent a coarse filtration by a piece of clean, white cotton. Then it was filtered through what man filter paper. The filtrate (Ethanol extract) obtained was taken for rotary vacuum evaporation (HAHNVAPOR-Rotary-Vacuum-Evaporator: HAHN SHIN SCIENTIFIC, South Korea). After drying the filtrate, dried adhesive powdered mass was obtained. This powdered mass was designated as crude extract. 10.72 gm free flowing crude extract was obtained from 450gm of dried powder material.

\section{Study of Antimicrobial Activity by Disk Diffusion Method}

Preparation of Microorganisms Used for The Activity Test: Microorganisms used for the activity test are Shigelladysenteriae, Escherichia coli, Staphylococcus aureus, Staphylococcus epidermidis and Shigellaflexneri, collected from the Microbiology Lab. of Pharmacy Discipline, Khulna University, Bangladesh. Composition of Nutrient agar media (Mast Diagnostics, Mast Group Ltd., Merseyside, U.K.) is used for culture and subculture purpose. Agar media, petridishes and other glassware were sterilized by autoclaving at a temperature of $121^{\circ} \mathrm{C}$ and a pressure of $15-\mathrm{lbs} / \mathrm{sq}$ inch for 15 minutes. Loop and forceps were kept in a laminar hood and UV light was switched on before one hour working in a laminar hood to avoid accidental contamination. Two subculture was proceeded and inoculated at $37^{\circ} \mathrm{C}$ for 24 hours to assure the growth of test organisms. Afterwards, single colonies from each bacterial isolates were subcultured in nutrient broth in tes tubes and taken for shaking incubator for overnight incubation in anaerobic condition.

Preparation of Test Sample: $100 \mathrm{mg}$ and $250 \mathrm{mg}$ of the leaf extract of Ludwigia adscendens (L.) H.Hara were accurately weighed by the electronic balance and taken in small volumetric flasks. Then small amount of methanol was added and triturated in unidirectional manner using a vortex mixer, after proper mixing the volume was adjusted to $4 \mathrm{ml}$ and $5 \mathrm{ml}$ respectively by methanol and the concentration of these solutions became $25 \mu \mathrm{g} / \mu \mathrm{l}$ and $50 \mu \mathrm{g} / \mu \mathrm{l}$. For petroleum ether part and chloroform part only $0.1 \mathrm{gm}$ and $0.2 \mathrm{gm}$ compounds were obtained respectively. So, these samples were prepared by addition of solvent calculatively so that desired concentration $(25 \mu \mathrm{g} / \mu \mathrm{l}$ and $50 \mu \mathrm{g} / \mu \mathrm{l})$ could be obtained.

\section{Disc Diffusion Method}

Three types of discs were used for antibacterial screening: Sample discs, Standard discs and Blank discs $(5 \mathrm{~mm}$ diameter each). Each agar plates were divided into four portions i.e. two for samples $(250 \mu \mathrm{g}$ and $500 \mu \mathrm{g})$, one for standard (positive control) and one for blank (negative control).

\section{Sample Disc Application}

The spatial arrangement of the discs was such that the discs were no closer than $15 \mathrm{~mm}$ to the edge of the plate and far enough apart to prevent overlapping the zones of 


\section{Advances in Pharmacology and Clinical Trials}

inhibition. $10 \mu \mathrm{l}$ of the test sample from $25 \mu \mathrm{g} / \mu \mathrm{l}$ and 50 $\mu \mathrm{g} / \mu \mathrm{l}$ solutions were applied on the discs with the help of a micropipette inside laminar air flow to get concentration $250 \mu \mathrm{g}$ and $500 \mu \mathrm{g}$ per disc respectively.

\section{Blank Disc Application}

$10 \mu$ l ethanol was applied on the blank discs as negative control. They ensure that the residual solvent's activity and the filter paper were not active themselves.

\section{Standard Disc Application}

Kanamycin $(5 \mu \mathrm{g} / \mathrm{disc})$ antibiotic discs were used as positive control to ensure the activity of standard antibiotic against the test microorganisms. Finally, the plates were incubated upside down at $37^{\circ} \mathrm{C}$ for $16-18$ hours.

\section{Study of Cytotoxic Activity by Brine Shrimp Model [14]}

\section{Preparation of Sea Water and Construction of Hatchery and Hatching of Brine Shrimp}

$38 \mathrm{~g}$ Sea salt (Pure sodium chloride $(\mathrm{NaCl}) 20 \mathrm{~g}$ and table salt 18g) were dissolved in distilled water to make one liter and then it was filtered off. Then sea water was taken to the flask. Around 0.5g amount Artemia was so ak to the water. The air pipe was adjusted to the bottom of the flask by having a weight. An electrical bulb was fitted near the flask to slightly warm up and to attract the hatched nauplii. This combination is kept for 18-24 hours to hatch the Artemia eggs. The hatched shrimps were attracted to light to collect them and they were taken for bioassay.

\section{Preparation of Stock, Standard and Control Solution}

About $16 \mathrm{mg}$ of dried ethanol leaf extract of Ludwigia adscendens (L.) H.Hara was taken in $25 \mathrm{ml}$ volumetric flask and volume of $25 \mathrm{ml}$ was adjusted by sea water. A few drops DMSO (Dimethyl sulfoxide) were added to dissolve the extract. The concentration of this solution became $640 \mu \mathrm{g} / \mathrm{ml} \&$ was considered as stock solution. In the case of standard solution about $0.25 \mathrm{mg}$ vincristine sulphate was dissolved in sea water and added same amount of DMSO as stock solution. The final volume was then adjusted to $25 \mathrm{ml}$ with sea water. The concentration of this solution became $10 \mu \mathrm{g} / \mathrm{ml}$. In the case of control solution about $25 \mathrm{ml}$ volumetric flask, same amount of DMSO was added and final volume was adjusted to $25 \mathrm{ml}$ with sea water.

\section{Application of Test Solution and Brine Shrimp Nauplii into the Test Tubes}

About 31 test tubes were taken among which 14 for sample (two same concentrations), 7 for control and 10 for standard (two same concentrations). Each test tube was marked to indicate $10 \mathrm{ml}$ volume. About $5 \mathrm{ml}$ stock solutions were added to a test tube and a serial dilution was made to make concentrations $320,160,80,40,20,10$ and $5 \mu \mathrm{g} / \mathrm{ml}$. Then $5 \mathrm{ml}$ stock solution of standard was added to a test tube and a serial dilution was made to provide $5,2.5,1.25,0.625$ and $0.325 \mu \mathrm{g} / \mathrm{ml}$. After then 10 nauplii were added to each of the test tubes and volume was adjusted to $10 \mathrm{ml}$ with sea water. The concentration of DMSO should not exceed $10 \mu \mathrm{l} / \mathrm{ml}$. After all, all of the test tube is kept for 24 hours for observation.

\section{Counting of Nauplii}

After $24 \mathrm{hrs}$ the test tubes were observed and the number of survived nauplii in each test tube was counted and the results were noted. From this, the percentage of lethality of brine shrimp nauplii was calculated at each concentration for each sample.

$\%$ Mortality $=[$ Avg. no. of alive shrimp of control - Avg. no. of alive shrimp of sample)/ Avg. no. of alive shrimp of control] $\times 100$

The test was performed in duplicate to avoid statistical error.

\section{Result}

The crude extract of the leaves of Ludwigia adscendens (L.) H.Hara was found antagonist to the selective isolated pathogens except Shigella dysenteriae and Staphylococcu $s$ aureus (Table 1) when, the zone of inhibition ranged between $2 \mathrm{~mm}$ to $11 \mathrm{~mm}$. In addition, the antagonism of the extract to the pathogens fluctuated with the changing of concentrations representing the dosage effects. On the other hand, the cytotoxic city based lethality of Ludwigia adscendens (L.) H.Hara to the brine shrimp nauplii was phenomenal (Table 2) when compared with vincristine sulphate as standard. Similar to the antimicrobial activity, the lethality range varies with the changed concentration of the test extract while, a linier correlation was observed between the progressive increasing of the leaf extract concentration with the increased lethality of brine shrimp nauplii(Figure 1) but in that case the standard was more significant (Figure 2) than the test extract. 


\section{Advances in Pharmacology and Clinical Trials}

\section{Discussion}

\section{Antimicrobial Activity Testing}

After proper incubation, the antibacterial activity of the test agent was determined by measuring the diameter of zone of inhibition in term of millimeter with a slide calipers.

The crude extract of the leaves of Ludwigia adscendens
(L.) H.Hara reflects mild antibacterial activity against the bacterial strains Escherichia coli, Salmonella typhi, Salmonella paratyphiandno activity against Shigella dysenteriae, Staphylococcus aureus. Standard antibiotic discs of Kanamycin were used for comparison purpose $[13,15]$. The obtained results provide a support for the use of this plant in traditional medicine and suggest its further advance investigation.

\begin{tabular}{|c|c|c|c|c|c|}
\hline \multirow{2}{*}{ Bacterial strains } & \multirow{2}{*}{$\begin{array}{l}\text { Type of } \\
\text { bacterial } \\
\text { strains }\end{array}$} & \multicolumn{3}{|c|}{ Diameter of Zone of Inhibition in Mm } & \multirow{2}{*}{$\begin{array}{c}\text { Negative } \\
\text { Control }\end{array}$} \\
\hline & & Standard (Kanamycin) $5 \mu \mathrm{g}$ & Extract $250 \mu \mathrm{g}$ & Extract $500 \mu \mathrm{g}$ & \\
\hline Shigella dysenteriae & $\operatorname{Gram}(-)$ & 23 & 0 & 0 & 0 \\
\hline Escherichia coli & $\operatorname{Gram}(-)$ & 23 & 3 & 7 & 0 \\
\hline Salmonella typhi & $\operatorname{Gram}(-)$ & 25 & 5 & 11 & 0 \\
\hline Salmonella paratyphi & Gram (-) & 24 & 2 & 5 & 0 \\
\hline Staphylococcus aureus & $\operatorname{Gram}(+)$ & 26 & 0 & 0 & 0 \\
\hline
\end{tabular}

Table 1: In vitro antibacterial activity of ethanol root extract of Ludwigia adscendens (L.) H.Hara.

\section{Cytotoxic Effect Testing}

The brine shrimp lethality bioassay is a rapid, simple and convenient technique. This is a popular method for identifying biological active compounds having cytotoxic activity in the crude extract. In this bioassay, the crude leaves extract of Ludwigia adscendens (L.) H.Hara showed lethality indicating the biological activity of the compound present in the extract. Test sample showed different mortality rate at different concentrations. The result of this assay directly resembles to the findings of the experiment conducted with Leucas aspera isolates [14].

\begin{tabular}{|c|c|c|c|}
\hline & Conc. $(\boldsymbol{\mu g} / \mathbf{m l})$ & Lower limit $(\boldsymbol{\mu g} / \mathbf{m l})$ & Upper limit $(\boldsymbol{\mu g} / \mathbf{m l})$ \\
\hline Extract & 96.6204 & 60.4891 & 195.6492 \\
\hline Standard & 0.7158 & 0.4123 & 1.0293 \\
\hline
\end{tabular}

Table 2: $\mathrm{LC}_{50}$ for Ludwigia adscendens (L.) H.Hara (test sample) and vincristine sulphate (standard) with lower and upper limit calculated by Ldp line software.

The $\mathrm{LC}_{50}$ caused by the test extract, as well as vincristine sulphate as standard were calculated by probit analysis software LdP (LdP Line software, USA) and was found to be $96.6204 \mu \mathrm{g} / \mathrm{ml}$ for Ludwigia adscendens (L.)
H.Hara leaf extract whereas $0.7158 \mu \mathrm{g} / \mathrm{ml}$ for vincristine sulphate. The research also reflects the similarity of output obtained from the research of [16]. 


\section{Advances in Pharmacology and Clinical Trials}

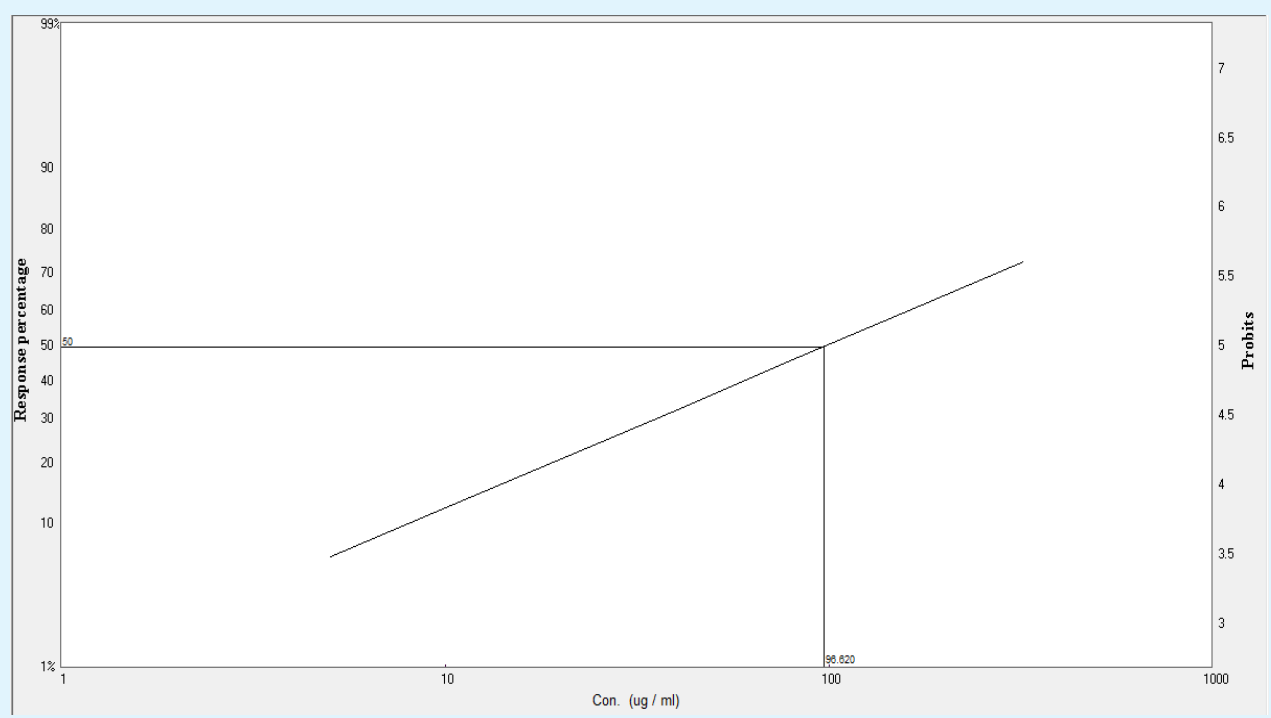

Figure 1: Graphical representation of brine shrimp lethality bioassay and $\mathrm{LC}_{50}$ for the ethanol leaf extracts of L.adscendens (L.) H.Hara by Ldp line software.

The mortality rate of the brine shrimp was found to be increased with the increasing of concentration of the extract and plotting of $\%$ mortality versus log

concentration on the graph paper produced an approximate linear correlation between them.

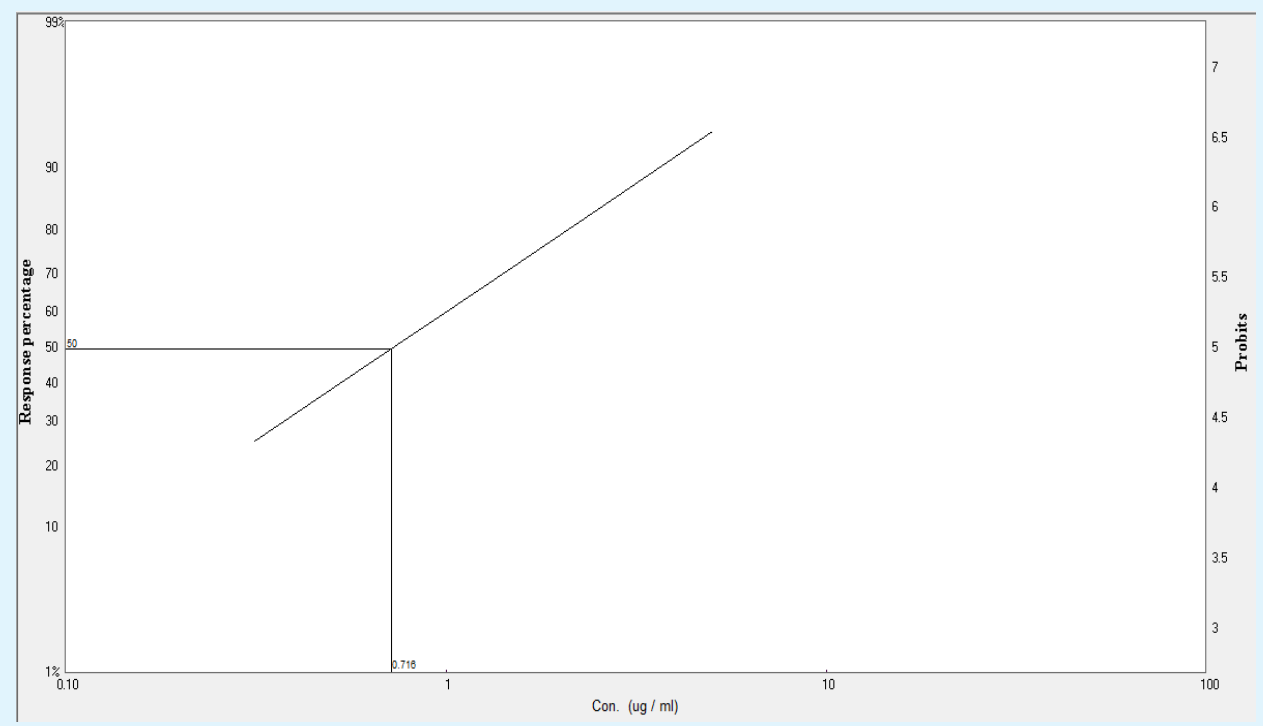

Figure 2: Graphical representation of brine shrimp lethality bioassay and $\mathrm{LC}_{50}$ for the standard (vincristine sulphate) by Ldp line software.

Linear correlation was found between \% mortality versus log concentration while determining LC 50 for the standard (vincristine sulphate). Result of the present study indicates that the leaf extract of Ludwigia adscendens (L) H. Hara might have compounds with biological activity with actions like enzyme inhibition, ion channel interference, antimicrobial, pesticidal and 


\section{Advances in Pharmacology and Clinical Trials}

cytotoxic activity. The LC50 obtained for the extract was enough to show cytotoxic activity.

\section{Conclusion}

These studies conclude that Ludwigia adscendens (L.) H. Hara provides antimicrobial activity against some Gram negative bacterial species when extracted and managed well. The cytotoxic activity of the leaf extract is less significant than that of vincristine sulphate, used as standard. This is an evidence of the authenticity of the data collected and their statistical analysis. In both the cases, dosage effects of the extract played important role in the final output of the experiments. HPLC or, NMR will be a good choice to identify all chemical groups present in the extract to know their function separately and precisely. The results provide a scientific basis for the centuries-old usages of aqueous extracts of this medicinal plant as compared to the prevalent established works with the other similar type of medicinal plants.

\section{Acknowledgements}

The authors are very grateful to the authority of Pharmacy Discipline and Biotechnology and Genetic Engineering Discipline of Khulna University, Bangladesh for their logistic support. At the same time, the contributions of Bangladesh University, Dhaka and BCSIR (Bangladesh Council of Scientific and Industrial Research) are deeply respected and memorized.

\section{Declaration}

\section{Consent for Publication}

Not applicable

\section{Availability of Data and Materials}

The data that support the findings of this study are available from the corresponding author upon reasonable request.

\section{Competing Interest}

The authors participated in this research activity have no competing interest with others.

\section{References}

1. Daniel F Austin (2002) Plant Resources of South East Asia No 12(2) Medicinal and poisonous plants 2. Bogor, Indonesia: Prosea Foundation 56(3): 297.
2. Burkill IH (2015) A dictionary of the economic products of the Malay Peninsula.

3. Chang CI, Ku CC, Chang JY, Kuo YH (2004) three new oleanane-type triterpenes from Ludwigiaoctovalvis with cytotoxic activity against two human cancer cell lines. J Nat Prod 67(1): 91-93.

4. Ahn NT, Cam PD, Dalsgaard A (2001) Antimicrobial resistance of Shigella spp. Isolated from diarrheal patients between 1989 and 1998 in Vietnam. South Asian J Trop Med Public Health 32(4): 856-862.

5. McGaw LJ, Jager AK, Van Staden J (2000) Antibacterial, anthelminthic and antiamoebic activity in South African medicinal plants. J Ethnopharmacol 72(1-2): 247-263.

6. Mathabe MC, Nikolova RV, Lall N, Nyazema NZ (2006) Antibacterial activities of medicinal plants used for the treatment of diarrhoea in Limpopo Province, South Africa. J Ethnopharmacol 105(1-2): 286-293.

7. Watt JM, Breyer-Brandwijk MG (1962) The Medicinal and Poisonous Plants of Southern and Eastern Africa ( $2^{\text {nd }}$ Edn.). Edinburgh: E \& S Livingstone Ltd.

8. (2004) FAO, Trade in Medicinal Plants, Economic and Social Department, Food and Agriculture Organization of the United Nations, Rome, Italy.

9. Sadhu SK, Phattanawasin P, Choudhuri M, Ohtsuki T,Ishibashi M (2006) Medicinal plants of Bangladesh with chemical constituents and uses Medicinal plants of Bangladesh with chemical constituents and uses.Journal of Natural Medicines 60(3): 258-260.

10. Yusuf M, Chowdhury JU, Wahab MA, Begum J (1994) Medicinal Plants of Bangladesh, Bangladesh Council of Scientific \& Industrial Research (BCSIR), Dhaka, Bangladesh, pp: 1-340.

11. Ghosh A, Misra S, Dutta AK, Choudhury A (1985) "Pentacyclic triterpenoids and sterols from seven species of mangrove," Phytochemistry 24(8): 17251727.

12. Park KD, Lee V, Kim SU, Kim SH, Sun WS, et al. (2004)

"Anticancer activity of 3- 0 -acyl and alkyl-(-)epicatechin derivatives," Bioorg Med Chem Lett 14(20): 5189-5192. 


\section{Advances in Pharmacology and Clinical Trials}

13. Abdullah-Al-Mamun M, Hasan MJ, Al Azad S, Uddin MG, Shahriyar S, et al. (2016) Evaluation of Potential robiotic Characteristics of Isolated Lactic Acid Bacteria from Goat Milk. British Biotechnology Journal 14(2): 1-7.

14. Sultana HMS,Alam I, Al Azad S, Adhikery D, Al-Mamun A (2018) Therapeutic potentiality assessment of Leucasaspera as an effective phyotochemical, neuropharmacological, antihelminthic, analgesic and selective lethal agent. Acad J Pharm Pharmacol 6(2): 24-31.
15. Abdel-Rahman LH, Abu-Dief AM, El-Khatib RM, AbdelFatah SM (2016) Sonochemical synthesis, DNA binding, antimicrobial evaluation and in vitro anticancer activity of three new nano-sized $\mathrm{Cu}$ (II), Co (II) and Ni (II) chelates based on tri-dentate NOO imine ligands as precursors for metal oxides. Journal of Photochemistry and Photobiology B: Biology 162: 298-308.

16. Solis PN, Wright CW, Anderson MM, Gupta MP, Phillipson JD (1993) A microwell cytotoxicity assay using Artemiasalina (brine shrimp). Planta med 59(3): 250-252.

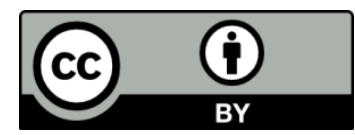

